Presença sensível: cuidado e criação na clínica psicanalítica

\title{
Presença sensível: cuidado e criação na clínica psicanalítica
}

\author{
Mônica Medeiros Kother Macedo
}

Pode-se supor que um livro, ou melhor, que o desejo de escrever um livro, nasça da motivação de um autor em compartilhar suas ideias. A partir do "nascimento" do livro, será por meio da acolhida de seus leitores que se traçará seu percurso singular. Neste encontro, entre o livro e seu leitor, novas ideias e interrogações se produzem, sendo que a qualidade desta incessante dinâmica confere ao texto um valor inestimável: a capacidade de fazer pensar e de se desdobrar na produção de novas inquietações. Assim é Presença sensível: cuidado e criação na clínica psicanalítica, do psicanalista Daniel Kupermann, sobre o qual tenho a satisfação de escrever e que traz em si, inegavelmente, uma rica potencialidade em seu devir.

A obra apresenta como fio condutor que conecta seus capítulos o exercício de um pensar reflexivo, interrogativo, criativo e autônomo a respeito da psicanálise. Como o próprio autor refere, 
seu livro é constituído de ensaios escritos durante um longo percurso por espaços institucionais e encontros pessoais diversos, que trazem à tona questionamentos que permitem pôr em evidência tanto o funcionamento das instituições psicanalíticas quanto a complexidade presente nas interações que têm lugar na clínica. Como pano de fundo de seu texto, sempre marca presença um pensamento original e vibrante a respeito da história, da teoria, da técnica e do método psicanalítico.

Presença sensível: cuidado e criação na clínica psicanalítica convoca seu leitor a um movimento de desacomodação mais do que necessário no panorama da psicanálise brasileira. Muito se tem falado - até mesmo à exaustão - da crise atual da psicanálise. No texto de Daniel encontramos não respostas, mas ferramentas para o enfrentamento daquilo que reside no âmago das críticas feitas à psicanálise: a questão da formação dos psicanalistas. Afinal, não é uma crise dos psicanalistas o que se desvela a um olhar mais atento? Falar em crise da psicanálise seria concordar com a falência de seus pilares: o inconsciente, a sexualidade, o recalcamento e a transferência, o que, convenhamos, não parece ser a questão. Portanto, a partir de um olhar acurado e atento, ao abordar os efeitos funestos da institucionalização da psicanálise, Kupermann descortina a desvitalização e a anestesia que deforma o modo singular da psicanálise de pensar e de refletir a respeito do humano e de seus padecimentos. Ironicamente, a mesma psicanálise, já acusada de corromper a moral e os bons costumes de uma sociedade repressiva, hoje passa a ser tida como "ultrapassada". Neste paradoxo de atributos, cabe resgatar a importância de um exercício clínico potente calcado em uma escuta ética, ou seja, resgatar a clínica psicanalítica como espaço habitado por uma presença sensível a partir da qual ocorrem processos de cuidado e criação. Reafirma-se, assim, o que, essencialmente, define a psicanálise como uma teoria aberta que surge para dar condições ao homem de desvencilhar-se da ignorância em relação a si mesmo e, desde o desamparo inerente a sua condição, ascender à liberdade como aquisição vital, que permite-lhe exercer sua capacidade de pensar o mundo e a si mesmo.

O exercício da clínica psicanalítica é apresentado ao leitor sempre de maneira a incluir em suas reflexões o processo de formação do analista. Será sua transferência primeira à psicanálise o ponto de partida para a problematização de seu fazer como analista. Nesta direção, o encontro analítico precisa contemplar a potência criativa de um encontro entre dois sujeitos, no qual a assimetria presente não constitua um espaço para o exercício do poder. Para isto se faz neces- 
sária a presença de um analista com autonomia em seu processo de aproximação e de apropriação da psicanálise. O analista, na configuração da clínica exposta na obra, é convocado em sua disponibilidade para ser uma presença efetivamente sensível e valorizada desde sua implicação no processo analítico, atributo essencial e indispensável para a existência de uma clínica psicanalítica na qual a criação seja possível.

Afirma-se assim, no texto, a relevância de um analista que se deixe afetar pela complexidade e diversidade das formas de expressão da dor psíquica. Processo de afetação que pode fazer com que uma clínica produza teoria, ou seja, com que surjam espaços para o não pensado, o não escrito e o não descoberto. Longe dos dogmas, a paixão pelo ato de pensar ganha força. A clínica do sensível produz sentido como efeito do irredutível encontro entre analista e analisando, no qual o primeiro, por meio da ética da escuta, se implica no campo de criar-ação do segundo. A criação do analisando, sempre singular, pode ser vista como expressão do potencial gerador dos espaços não aprisionados "pelas amarras do legal, do contratual ou do institucional" (p. 177).

É impossível ao leitor, diante do exposto, ficar indiferente à forma como se presentifica no livro uma pertinente provocação para que se pense nas condições de escuta do psicanalista. Provocação, aliás, muito apropriada, considerando-se, especialmente, a diversidade do psicanalisar nos tempos atuais. A definição do que seria a disponibilidade para o encontro com a alteridade põe em evidência uma verdadeira exigência ética, a saber, a necessidade de uma análise autêntica e não burocrática para o psicanalista.

No livro de Daniel Kupermann, o leitor encontrará revigoradas e ampliadas muitas das contribuições presentes na história da psicanálise. Por meio de uma fecunda atividade, ao fazer trabalhar aportes de Sigmund Freud, Sándor Ferenczi e Donald Winnicott, o autor expõe uma rica tessitura feita a partir de reflexões, inquietudes e contribuições que se colocam a serviço do exercício de uma psicanálise muitas vezes atrofiada em seu potencial pelo efeito tanático do engessamento promovido em rígidos espaços institucionais.

Um aspecto a mais que deve ser destacado na leitura de Presença sensível é a precisão com que os conceitos são apresentados e problematizados ao longo do livro. Daniel Kupermann nos conduz a paisagens instigantes dos cenários clínico e metapsicológico, da política, do cinema, da cultura, das instituições psicanalíticas, ou ainda da Educação, ao nos brindar com o humor presente nas histórias do malicioso "Juquinha" - personagem da nossa cultura cômico-popu- 
lar - frente aos enigmas da sexualidade, reafirmando o valor criativo da pulsão de saber, por vezes, menosprezado.

A leitura de Presença sensível: cuidado e criação na clínica psicanalítica permite-nos constatar que estamos diante de um autor que vem construindo uma importante trajetória na psicanálise, e que convida seu leitor a compartilhar o resultado de um processo criativo - o nascimento de um livro gerado com prazer. À medida que avançamos na leitura dos capítulos do livro de Kupermann, desvela-se, também, seu processo de apropriação da herança psicanalítica. Assim, na delicadeza de seus escritos, na precisão conceitual apresentada, na crítica acurada e na análise das obras abordadas, Daniel problematiza e regenera o legado psicanalítico. Goethe considerava que, frente ao recebimento de uma herança, é necessário que o sujeito execute um trabalho de apropriação e de conquista do recebido. E que belo trabalho fez Daniel que, com sua generosidade de escritor, nos concede o privilégio de compartilhar! Pode-se afirmar, ao final da leitura, que criar continua sendo a melhor maneira de fazer-se sensivelmente presente na vida, e de dar futuro ao legado psicanalítico que herdamos.

\section{Mônica Medeiros Kother Macedo}

Psicanalista, doutora em Psicologia pela Pontifícia Universidade Católica do Rio Grande do Sul (Porto Alegre, RS, Brasil), professora da Faculdade de Psicologia da Pontifícia Universidade Católica do Rio Grande do Sul (Porto Alegre, RS, Brasil) e membro pleno da Sociedad Psicoanalitica del Sur de Buenos Aires (Buenos Aires, Argentina).

Rua Florêncio Ygartua, 69/ 307

90430-010 Porto Alegre, RS, Brasil

e-mail: monicakm@pucrs.br 
Rev. Latinoam. Psicopat. Fund., São Paulo, v. 13, n. 1, p. 144-149, março 2010

Eronem, M.

Mental Disorders and Homicidal Behaviour in Female Subjects. American Journal of Psychiatry, v. 152, n. 8, p. 1216-1218, August, 1995.

Taylor, P.; Gunn, J. Homicides by People with Mental Ilness: myth and reality. The British Journal of Psychiatry, v. 174, n. 1, p. 9-14, January, 1999.

Scwartz, R.; Reynolds, C.; Austin, J. Homicidality in Schizophrenia: a replication study. American Journal of Orthopsychiatry, v. 73, n. 1, p. 74-77, 2003.

Joyal, C.; Putkonen, A.; Paavola, P.; Tiihonen, J. Characteristics and Circumstances of Homicidal Acts Commired by Offenders with Schizophrenia. Psychological Medicine, v. 34, p. 433-442, 2004.

Valença, A.; Moraes, T.

Relação entre Homicídio e Transtornos Mentais. Revista Brasileira de Psiquiatria, v. 28 (supl. II), p. S62-68, 2006.

Valença, A. Aspectos Psicopatológicos e Forenses de Mulheres Homicidas com Diagnóstico de Transtornos Psicóticos Primários Jornal Brasileiro de Psiquiatria, v. 57, n. 4, p. 253-260, 2008. 